\title{
Religionshistorie og aksetid
}

\section{Om Robert Bellahs udkast til en evolutionær religionshistorie}

\author{
HANS J. LUNDAGER JENSEN
}

ENGLISH ABSTRACT: The article presents and discusses two articles by Robert Bellah, "Religious evolution" from 1964 and "What is Axial about the Axial Age?" (2005). In what seems to be a general lack of interest in a history of religion (different from a history of religions) among academic scholars in the science of religion, Bellah's model, especially in its combination with recent approaches to the 'axial age' and to Merlin Donald's biocultural cognitive model for hominid evolution, is recommended as a useful starting point for the revitalization of an honorable branch of religious studies.

DANSK RESUMÉ: Artiklen præsenterer og diskuterer to artikler af den amerikanske religionssociolog Robert Bellah, "Religious evolution" fra 1964 og "What is Axial about the Axial Age?" (2005). I forhold til en generel mangel på interesse for en religionens historie (forskellig fra religionernes historie) blandt religionsvidenskabelige forskere anbefales Bellahs model som et frugtbart udgangspunkt for en revitalisering af en hæderværdig del af religionsvidenskaben, særlig når den kombineres med aktuelle diskussioner af 'aksetiden' og Merlin Donalds biokulturelle, kognitive model for hominid evolution.

KEYWORDS: religionshistorie; Robert Bellah; aksetid; evolution; adaptation; velsignelsesreligion; skriftlighed

\section{Religionshistorie?}

I en tid, hvor der ellers skrives, sælges og læses historier om alt muligt, er religionens historie ikke et specielt dominerende tema for repræsentanter for det akademiske fag 'religionshistorie'. Religionen er sikkert et større og mere uhåndgribeligt emne end 
torsk, kartofler, farven blå eller himlen; men det er nok ikke mere kompliceret end selve livet? ${ }^{1}$ Måske forekommer kategorien religionshistorie gammeldags sammenlignet med kategorien religionsvidenskab?2 Men kategorien bruges fortsat i de danske, religionsvidenskabelige uddannelser. ${ }^{3}$

Det er formentlig noget uklart, hvad orddelen 'historie' i 'religionshistorie' egentlig betyder. To store og i sin tid meget brugte håndbøger fra midten af det 20. årh., den svenske Religionerna i historia och nutid og den danske Illustreret religionshistorie, havde begge ordet 'historie' i deres titler. ${ }^{4}$ De var begge opbygget som sideordnede gennemgange af enkelte religioner, hver med sin historie; derimod havde 'religion' som sådan ikke en historie. Dette ser ud til at gælde også for religionshistorien endnu i dag, i Danmark og formentlig i vidt omfang internationalt. ${ }^{5}$

\section{Robert Bellah, evolution, adaption}

I 1964 publicerede den amerikanske religionssociolog Robert Bellah en artikel med titlen "Religious Evolution", der skitserede en linje i religionens historie, fra de tidligste til de helt nutidige. ${ }^{6}$ Denne religionshistorie blev tænkt inden for rammerne af en evolutionsteori. I artiklen tematiserede Bellah selv sit forslags usamtidighed. Evolution var generelt ikke et populært begreb i socialvidenskaberne i det 20 årh. efter første verdenskrig; men modviljen imod evolutionstænkning var ganske særlig udtalt i netop religionsvidenskaben:

But by the third decade of the 20th century the evolutionary wave was in full retreat both in the general field of science of religion and in the sociology of religion in particular. Of

1 Torsk: Kurlansky 1998; kartofler: Reader 2009; farven blå: Pastoureau 2000; himlen: McDannell, \& Lang 1988; selve livet: Dawkins 2004.

2 De to begreber var ligestillede allerede i Edvard Lehmans artikel i Salmonsens Leksikon (1925).

3 I uddannelsen i religionsvidenskab ved Aarhus Universitet indgår religionshistorie i det obligatoriske kursus i første semester i "Religionshistorie med religionsfænomenologi". Ved religionsvidenskab ved Københavns Universitet udbydes en særlig kandidatuddannelse i religionshistorie, og tidsskriftet Chaos præsenterer sig som et "tidsskrift for religionshistoriske studier".

4 Illustreret religionshistorie: Asmussen \& Læssøe, eds., 1968

5 Tilsvarende i Gyldendals religionshistorie (1994); artiklen om religionshistorie i Den Store Danske Encyklopædi (Geertz 2000). Det nyere tyske oversigtsværk, Religionen und Kulturen der Erde (Grabner-Haider \& Prenner eds., 2004) har en kort historisk skitse frem til historisk dokumenterede religioner, derefter kun sideordnede fremstillinger. I den indflydelsesrige Encyclopedia of Religion (1987) drejede Ugo Bianchis artikel "History of Religions" sig om religionernes historie, men indeholdt dog en skitse til en historisk-typologisk sondring mellem 'indfødte' ('native') og 'grundlagte' ('founded') religioner; jf. senere i denne artikel om Assmanns sondring mellem 'primære' og 'sekundære' religioner. Guide to the Study of Religion (Braun \& McCutcheon, eds., 2000) omfatter 31 væsentlige emneområder for religionsvidenskab, fra 'Religion til 'Play'; 'historie' er ikke et af dem.

6 Det er i denne sammenhæng ikke relevant, at Bellah normalt betragtes som religionssociolog, ikke som religionshistoriker. Hans forslag i artiklen til en evolutionær beskrivelse er 'religionshistorie' i ordets mest umiddelbare og elementære forstand. 
course, this was only one aspect of the general retreat of evolutionary thought in social science, but nowhere did the retreat go further nor the intensity of the opposition to evolution go deeper than in the field of religion (Bellah 1964, 358). ${ }^{7}$

Samtidens religionsvidenskab var faktisk immun over for de tanker og perspektiver, som artiklen fremlagde, og den fik ingen virkning. Robert Bellah blev berømt alligevel, men som forfatter til den artikel om 'civil religion', som revitaliserede Rousseaus begreb og gjorde det almenkendt. Men efter min mening bør religionsvidenskaben nu indhente det forsømte, tage Bellahs forslag til efterretning og gendefinere en religionshistorie, der fortjener sit navn.

Det teoretiske grundlag for Bellahs artikel var et systemteoretisk begreb om evolution, der bl.a. var formuleret af sociologen Talcott Parsons, der i øvrigt introducerede både Émile Durkheim og Max Weber i en amerikansk kontekst. Begrebet er kun ganske kort skitseret af Bellah, men kan genfindes, i en mere udviklet og mere sofistikeret udgave, hos Roy A. Rappaport. ${ }^{8}$ I udgangspunktet antages, at de størrelser, der undergår evolution, er de, der eksisterer i kraft af reproduktion af sig selv. Sådanne størrelse betragtes som 'systemer' (hos Rappaport: 'levende systemer'). Plante- eller dyrearter er systemer; sten og skyer er ikke. Menneskearten er et system; men i denne tankegang vil også menneskeskabte dannelser som sprog, stater og religioner være systemer. Systemer 'persisterer', altså eksisterer over tid, i kraft af udvekslinger med en omverden, der forsyner systemet med essentielle elementer for dets eksistens. Fx kan en menneskekrop betragtes som et system (og menneskekroppe er i øvrigt en slags biotoper, hvor kroppen giver husly for talrige bakterielle organismer); kroppen lever kun, hvis den forsynes med ilt, føde osv. Allerede i Durkheims religionsteori i Formes élémentaires var det en markant ide, at religioner kan betragtes som en slags væsener, hvis eksistens forudsætter, at mennesker interesserer sig for dem. Som sprog kun findes, hvis der er mennesker, der benytter sig af dem, stater kun, hvis der er indbyggere, myter kun, hvis de fortælles, og ritualer kun, hvis de udføres, således findes religioner kun, hvis der er mennesker, der tilhører dem. Mennesker kan altså betragtes som sprogs, staters, religioners omverden. ${ }^{9}$

7 Bellah tilføjede: “An attempt to explain the vicissitudes of evolutionary conceptions in the field of religion would be an interesting study in the sociology of knowledge but beyond the scope of this brief paper". Her, næsten 50 år senere, vil det stadigvæk være et interessant emne.

8 Særligt Rappaport 1979, 145-147; 1999, 408-410. Jeg fremhæver Rappaport her, fordi han er umiddelbart relevant for religionsvidenskaben; hans egne referencer tilbage til Gregory Bateson, Lawrence Slobodkin etc. findes i de nævnte titler.

9 Durkheim 1994, 495f.: "D'une part, l'individu tient de la société le meilleur de soi-même, tout ce qui lui fait une physionomie et une place à part parmi les autres êtres, sa culture intellectuelle et morale (...) Mais d'un autre côté, la société n'existe et ne vit que dans et par les individus" ('På den ene side har individet fra samfundet fået den bedste side ved sig selv, alt det, der giver individet en særegenhed og en plads mellem andre livsformer, nemlig dets intellektuelle og moralske kultur (...) Men på den anden side eksisterer og lever samfundet kun i og igennem individerne'). I citatet her kan man med 'samfund' forstå 'religion'. Durkheim besvarer altså både det normale og mere trivielle spørgsmål, hvordan (eller om) religion gavner mennesker, og det omvendte spørgsmål. 
Bellahs definerede evolution således:

Evolution at any system level I define as a process of increasing differentiation and complexity of organization which endows the organism, social system or whatever the unit in question may be, with greater capacity to adapt to its environment so that it is in some sense more autonomous relative to its environment than were its less complex ancestors (Bellah 1964, ib.).

I Bellahs definition på evolution ses det systemteoretiske grundlag tydeligt: "at any system level", "organism, social system or whatever unit in question". Desuden beskrev Bellah den evolutionære proces som en målrettet bevægelse i retning af stigende kompleksitet indadtil i systemet og stigende autonomi udadtil i forhold til omverdenen. Her knyttede Bellah an ved Weber: Religionens historie antages at bevæge sig i retning af det mere differentierede og mere rationaliserede. ${ }^{10}$ Dette er givetvis et kompliceret punkt.

For det første er det ikke givet, at den differentieringsproces, der har fundet sted fra de tidligste kulturer og frem til moderniteten, og som også har omfattet religion, bedst skal forstås som en intern, religiøs differentiering. Durkheim fx ville snarest beskrive processen omvendt, fra den elementære religion, der burde betragtes som en slags oprindelig syntese, hvor alle eller næsten alle menneskelige forståelsesformer potentielt var til stede i religionen som alle menneskelige aktiviteters moder, og så frem til det modernes uddifferentiering af selvstændige funktionsfelter som $\mathrm{fx}$ filosofi, videnskaber og kunst. ${ }^{11}$ Ifølge denne opfattelse indebar differentieringerne også, at de selvstændige funktionsområder efterlods kunne vende sig imod deres ophav og sætte sig for at konkurrere med religion, som fx videnskabelige forklaringer over for mytologiske (eller fx Richard Wagners opera som alternativ til gudstjenester). Durkheim selv fastholdt ganske vist, at videnskab kun kunne erstatte religion på de felter, der reelt henhørte under videnskab, dvs. ikke, hvad moral og emotionalitet angår.12

For det andet og mere principielt vil det, uanset om religionens historie i øvrigt med fordel kan beskrives som en differentieringsproces af den ene eller den anden art,

10 Bellah 1964, 365: “(...) religious symbolization (...) tends to change over time, at least in some instances, in the direction of more differentiated, comprehensive, and in Weber's sense, more rationalized formulations".

11 Durkheim 1994, 12: "Si la philosophie et les sciences sont nées de la religion, c'est que la religion elle-même a commencé par tenir lieu de sciences et de philosophie" ('Hvis filosofien og videnskaberne er født ud af religionen, skyldes det, at religionen selv er begyndt som pladsholder for videnskaberne og filosofien'). Jf. s. 544 om kunst.

12 Jf. Durkheim 1994, 613: „Issue de la religion, la science tend à se substituer à cette dernière pour tout ce qui concerne les fonctions cognitives et intellectuelles" ('Videnskaben, der er udgået fra religionen, stræber efter at erstatte denne, hvad angår kognitive og intellektuelle funktioner'); s. 614: “(...) en tant que la religion est action, en tant qu'elle est un moyen de faire vivre les hommes, la science ne saurait en tenir lieu, car si elle exprime la vie, elle ne la crée pas" ('religion som handling, som en måde, hvorpå mennesker kan leve, kan videnskaben ikke indtage dens plads, for selv om den udtrykker livet, skaber den det ikke'). 
formentlig være tilstrækkeligt med en minimal forståelse af evolution, der fastholder forandring uden at implicere nogen bestemt retning af forandringen. Den proces, der frembringer evolution, er adaptation, altså systemets tilpasning til dets omverden. Men som det fremgår af den fremstilling, Roy Rappaport har givet af forholdet, er det afgørende ved adaptation alene det forhold, at systemet forbliver i kontakt med sin omverden, ikke hvordan. ${ }^{13}$ Det bagvedliggende ræsonnement er dette: Omverdenen er under permanent forandring (også selv om forandringens hastighed med menneskelig målestok kan synes at være uendelig langsom). Når et system per definition forudsætter kontakt med omverdenen for at eksistere, og når omverdenen per definition altid er under forandring, må et system, der ikke selv forandrer sig, i sagens natur på et eller andet tidspunkt komme ud af kontakt med sin omverden og dermed ikke fortsat kunne eksistere. Den forandring af et system, der er nødvendig, for at systemet fortsat er i en sådan kontakt med sin omverden, at det fortsat overhovedet kan eksistere, kan man betragte som det nødvendige og tilstrækkelige indhold i termen 'adaptation'.14 Det kan altså også være adaptation, hvis et system fx forandres fra en mere til en mindre kompleks organisation, som fx når en erhvervsvirksomhed i en krisetid og for at overleve skærer tilkomne funktioner fra for at vende tilbage til sin 'kerneydelse'. ${ }^{15}$ Den lutherske reformation i den kristne kirke i 1500-tallet kan betragtes som et analogt tilfælde. Den komplekse organisation, med vidtforgrenede, internationale relationer og et elaboreret, hierarkisk sæt af funktioner, bl.a. et differentieret ordensvæsen og et antal præstelige indvielsesgrader, som den romersk-katolske kirke var, blev i de protestantiske fyrste- og bystatskirker til betragteligt forenklede organisationer.

Disse to kritiske bemærkninger til Bellahs definition anno 1964 af evolution gives her kun for fuldstændighedens skyld. De er ikke tilstrækkelige til at afmontere de positive og frugtbare ansatser i Bellahs skitse for religionens historie. Desuden gav Bellah selv to vigtige tilføjelser til sin definition af evolution:

13 Det centrale punkt i Rappaports betragtning er, at adaptation grundlæggende ikke er en strategi for optimering, men for overlevelse (jf. at kommercielle virksomheder ikke som sit primære formål kan have at tjene flere penge, men overhovedet at tjene penge, og at universiteter ikke, i sidste instans, eksisterer for at uddanne flere studerende og publicere mere og bedre forskning ...).

14 Problemet her er, at der i begrebet 'adaptation' normalt underforstås et kvalitativt moment, dette at systemet 'forbedres'. Således defineres adaptation i Den Store Danske Encyklopædi som "ændringer i levende organismers struktur, funktion eller adfærd, der øger tilpasningen til omgivelserne" og af evolutionsbiologen Ernst Mayer $(2002,310)$ som "Any property of an organism believed to add to its fitness". Den 'forøgelse', som begge disse definitioner peger på, skal vel ses i forhold til den formindskelse af systemets tilpasning til dets omverden, som ellers ville være indtruffet, hvis den pågældende adaptation ikke var sket. Resultatet af adaptionen vil i dette tilfælde vel strengt taget ikke være en 'forøgelse' af systemets tilpasning til omverdenen, men en bevarelse af denne tilpasning. Encyklopædien fortsætter da også: “Da miljøet ændrer sig hele tiden, vil organismernes adaptationsgrad aldrig være optimal, og adaptation som proces vil fortsætte kontinuerligt".

15 Måske kan downsizing sammenlignes med zoologisk 'ø-dværgvækst' ('insular dwarfism'), altså en formindskelse af størrelse, hvis dette er en fordel for artens persistens? (Jf. "Insular dwarfism", engelsk Wikipedia). 
I do not assume that evolution is inevitable, irreversible or must follow any single particular course. Nor do I assume that simpler forms cannot prosper and survive alongside more complex forms (Bellah, ibid.).

Den første indskrænkning peger delvis i samme retning som den mere minimalistiske forståelse, bortset fra at man nok kan spørge, om ikke evolution så faktisk er uundgåelig i princippet (om end argumentationen begynder at ligne et cirkelræsonnement som jeg her gerne vil tage på mig): Tilfælde af, at der ikke har fundet nogen påviselig evolution sted, vil gælde tilfælde, hvor omverdenen endnu ikke har ændret sig tilstrækkeligt. Den anden indskrænkning er vigtigere: Udviklingen af nye systemer indebærer ikke, at ældre systemer dermed har mistet deres muligheder for at eksistere. ${ }^{16}$ Jeg skal vende tilbage til dette vigtige punkt nedenfor.

\section{Religionens historie ifølge Bellah}

På baggrund af disse to fornuftige forbehold foreslog Bellah nu at betragte religionens historie som et forløb med fire eller fem faser, fra den ældste og enkleste form og frem til religion i 1960'ernes USA; usikkerheden om antallet af faser kom af, at Bellah ikke var sikker på, om den fjerde fase burde betragtes som en selvstændig fase eller snarere en overgang. Han valgte at beskrive de enkelte faser som idealtyper i Max Webers forstand (Bellah 1964, 361) ud fra fire parametre: (1) religiøse symbolsystemer, dvs. ontologiske forestillinger, myter, kosmologier, etiske værdisystemer; (2) religiøse handlinger, dvs. de handlinger, der direkte er religiøst relaterede og motiverede; (3) religiøs organisation, dvs. de forskellige sociale roller, som en given religion omfatter; og (4) de implikationer for resten af samfundet, som en given religionsfase matte have. Bellah skelnede fem faser: den primitive, ${ }^{17}$ den arkaiske, den historiske, den tidligt-moderne og den moderne. Da faserne er teoretiske konstruktioner, vil det ikke være overraskende, at religioner på bestemte tidspunkter og sted kan opvise træk fra flere faser samtidig (s. 361).

Da artiklen som sagt ikke synes hidtil at have haft den betydning, som den efter min mening burde have haft, vil jeg her bruge noget plads på at parafrasere, og på enkelte punkter også kommentere, dens hovedpunkter.

16 Selv om man måske kan overveje, om ældre systemers fortsatte eksistens ikke i det mindste forudsætter adaptation i den forstand, at de har erhvervet evnen til at fungere sammen med nyere systemer.

17 I sin follow-up artikel fra 2005 (s. 69), som jeg skal vende tilbage til nedenfor, erstattede Bellah ordet 'primitive' med 'tribal' med den sædvanlige begrundelse, at ordet 'primitiv' kan virke fordomsfuldt og nedsættende. Men dels er det vanskeligt at gengive 'tribal' på dansk (ordbogens 'stamme'-' forekommer kun i sammensætninger, hvilket tvinger ubehjælpelige konstruktioner som 'stammemæssige', 'stammerelaterede'), dels kan man her påberåbe sig antropologisk autoritet, nemlig Mary Douglas' forsvar for termen 'primitiv' i antropologien (Douglas 1966, 92f). 
I den primitive religionsform er den religiøse symbolverden ubestemt og lokal. Myternes aktører er væsener med en flydende identitet, typisk mellem dyr og mennesker, snarere forfædre og ånder end egentlige guder, og fortællingernes rum er den nære verden, med særligt fremtrædende klipper, træer, slugter osv. Kosmologien er monistisk i den forstand, at den menneskelige, kendte verden og den sfære, som forfædre og ånder tilhører, og som normalt er adskilte, alligevel interagerer, enten ved at den trivielle verden er indlejret i den mere omfattende 'anden verden', eller ved, at den menneskelige verden omlejrer punktvise manifestationer af forfædrenes og åndernes verden, som fx ved lokale helligsteder. Religiøse handlinger består af ritualer, hvis kerne er en momentan identifikation mellem ritualdeltagerne og de mytologiske aktører; den dagligdags verden og den mytiske verden bringes til at participere i hinanden i ritualets forløb. Der er ingen speciel religiøs organisation i betydningen af særlige embeder eller særlige religiøse kompetencer, bortset fra den, som gruppens ældste eller en gruppes ledere til enhver tid må besidde; dog kan der findes individer med særlige kompetencer som fx shamaner. Religion er ikke et særligt felt, der kan skelnes fra andre felter; forskelle mellem køn, aldersgrupper og segmenter af samfundet som fx klaner som dele af en større stamme er også samtidig religiøse forskelle.

Bellah tog som eksempler indfødte australske kulturer og Navajo-stammen fra Arizona, USA. Man kan tilføje, at karakteristikken af primitiv mytologi bekræftes af det amerikanske materiale, som Claude Lévi-Strauss baserede sine mytologistudier på. Der findes også spredte eksempler i mytologier fra kulturer på senere evolutionære trin, fx i GT den fortælling, der gerne kaldes 'Jakobs kamp med englen' (Gen 32,23-33). 'Englen' her er udtryk for en senere (arkaisk præget) fortolkning, der ikke er begrundet i teksten, hvor Jakob netop kæmper med 'en mand', der er guddommelig, dvs. tilhører en anden, 'guddommelig' verden, uden at hans identitet bliver klar; begivenheden finder sted ved floden Penuel, der er realistisk nok.

Arkaisk religion adskiller sig fra primitiv religion på en række afgørende punkter. Den religiøse symbolverden omfatter aktører, der mere ligner almene forestillinger om guder, som i græsk eller nordisk mytologi, altså antropomorfe figurer med personlighed, køn, alder og bestemte funktionsområder (krig, jagt, kærlighed, agerbrug, smedekunst etc.). Kosmologien er fortsat monistisk; men forskel og afstand mellem den menneskelige verden og den anden verden er tydeligere trukket op, og muligheden for menneskelig participation i den anden verden er reduceret eller forsvundet. Guderne er her aktører, der bestyrer verden eller sektioner af den. De religiøse handlinger i den arkaiske form er følgelig interaktion imellem guder og mennesker: Guddommene giver frugtbarhed og beskyttelse til mennesker og andre jordiske væsener. Menneskene henvender sig til guderne med bønner og gaver (ofringer); hvis guderne tillige har permanente jordiske boliger, templer, påhviler det menneskene at drage omsorg for dem. Arkaisk religion har en differentieret religiøs organisation med personer med særlige kompetencer, altså præster og andet specialiseret kultpersonale. Dermed er religion blevet en særlig sektor i samfundet, ved siden af andre: økonomi, handel, retsvæsen, militær. Men den religiøse sektor og de øvrige sektorer er bundet sammen 
'oppefra' ved en sakralisering af den politiske magt; mere eller mindre sakrale konger fungerer både som ypperstepræster, som lovgivere, som hærførere etc. ${ }^{18}$

Ifølge Bellah kan man se eksempler på arkaisk religion i afrikanske og polynesiske religioner, amerikanske (formentlig amerikanske højkulturer) og i de ældst kendte religionsformer i Indien, Den Nære Orient og Kina. Man kan uden tvivl tilføje antikke, mediterrane kulturer (græsk, romersk) og fx nordisk religion. I forlængelse af Bellah kan man se eksemplariske udtryk for arkaisk religion i den babylonske kosmologiske oprindelsesfortælling Enuma elish, den græske Prometheusmyte om den menneskelige eksistens oprindelse eller den nordiske mytologis kampe mellem aser og vaner og mellem guder og jætter. Den markante forskel på og afstand imellem guder og mennesker er udtrykt i mytiske fortællinger om mislykkede muligheder for at forene det guddommelige og det menneskelige: den babylonske Gilgamesh, den gammeltestamentlige 'syndefaldsberetning' eller Homers Odysseus, der foretrækker den jordiske Penelope for den guddommelige Kalypso. Den arkaiske religions mest imponerende fænomener er oldtidens gigantiske tempelarkitektur som Esangila i Babylon, Amontempelkomplekserne i det egyptiske Theben og Athens Akropolis. Ved siden af offeret, som Bellah fremhæver som en essentielt arkaisk, religiøs handling kan man nok nævne offentlige processioner med gudebilleder som et særlig spektakulært træk. Den arkaiske religionsform er grundlæggende bekræftende og legitimerende. Kommunikationen mellem mennesker og guder sigter på at bevare eller retablere en ideel, jordisk tilværelse og orden, materielt, socialt og politisk. Den kan derfor også betegnes som 'velsignelsesreligion'; opmærksomheden ligger på det jordiske liv, hvis ideelle form opfattes som skrøbeligt og derfor med behov for beskyttelse eller, i særligt kritiske situationer, for genoprettelse af en orden, hvis model, 'arketype' om man vil, er henlagt i en mytisk fortid.

Den 'historiske' religionsform betegner et afgørende nybrud i religionens historie. Betegnelsen går alene på, at de religioner, der tilhører denne form, er relativt sent tilkomne i historien og at de falder i en periode, der under alle omstændigheder henhører under (eller også under) historien, ikke (blot) arkæologien eller antropologien. Ca. i midten af det første årtusind f.Kr. dukker der strømninger op i et område, der strækker sig fra Kina over det nordlige Indien og Den Nære Orient til Middelhavsområdet. Selv om konfuzianisme og daoisme, upanishademystik og buddhisme, iransk dualisme, israelitisk profeti og platonisk filosofi indbyrdes adskiller sig på en mængde punkter, er de alle udtryk for en nyorientering, der i det religiøse symbolsystem bryder med grundlæggende antagelser i den antikke religionsform. Et af de mest basale fælles træk synes at være, at der nu gives mulighed for at tænke og formulere principielle alter-

18 En af fordelene ved en historisk-evolutionær model som Bellahs er, at man dermed kan se, at en religionsdefinition som James George Frazers identificerede arkaisk religion med religion overhovedet: "a propitiation or conciliation of powers superior to man which are believed to direct and control the course of nature and of human life. Thus defined, religion consists of two elements, a theoretical and a practical, namely, a belief in powers higher than man and an attempt to propitiate or please them" (Frazer 1957, 65f). 
nativer til den givne orden: kosmologisk, politisk, socialt og/eller moralsk. Den arkaiske religion ville opretholde eller genoprette verden og forudsatte dermed, at verden var værd at oprette eller genoprette. Forskellen mellem den erkendte, trivielle verden og en anden sfære kan i den historiske religionsform accentueres til en dualistisk modsætning, der drager verdens hidtil naivt accepterede værdifuldhed i tvivl. Materielle og sanselige goder betragtes som mere eller mindre illusoriske. Den menneskelige død, der i arkaisk religion var et faktum, der blev taget ad notam uden principiel patos, kan nu blive et problem. Religionens opgave er ikke længere at berige menneskene i verden, men at frigøre dem fra eller befri dem fra verden. 'Mennesker' vil her ikke primært sige lokale væsener, rodfæstet i en bestemt lokalitet og kultur, men mennesker i almindelighed, i en generel fremmedgørelse over for den foreliggende verden og med et begær efter en anden tilværelsesform. I nærorientalsk-mediterrane udgaver, ikke mindst i kristendommen, bliver begæret præciseret som delagtighed i en guddommelig, evig og himmelsk tilværelse, uden arbejde, seksualitet, vold, sygdom og død; religionens opgave bliver typisk at frelse (løskøbe, redde) mennesker fra den jordiske tilværelse. I den indiske udgave er religionens formål at levere en erkendelse, en oplysning, der befrier mennesker fra begær efter det, der tælles som jordiske værdier, og som fastholder mennesker til materiel tilværelse (i en cyklus af genfødsler). I den græske filosofi indføres der en skelnen mellem det egentlige, de platoniske ideer, og deres mere eller mindre mangelfulde realiseringer i den materielle virkelighed. Religiøse handlinger bliver her vendt imod den givne orden, religiøst, socialt og politisk; at handle religiøst er at trække sig ud af den givne orden, ikke at bidrage til at opretholde den, og leve i overensstemmelse med særlige regler og tabuer. På det organisatoriske plan kan der danne sig elitære grupper, der så vidt muligt isolerer sig fra det normale, menneskelige liv, underlægger sig afsavn (seksuelle, alimentære, vestimentære, kommunikative tabuer), som i indiske og vestlige monastiske samfund. Samfundsmæssigt kan religionen hermed etablere sig som en decideret modmagt til politisk og arkaisk-religiøs magt; religiøst aktive mennesker kan vende det normale samfund ryggen, eller de kan kritisere og underminere gældende politiske og sociale strukturer og magtforhold; der kan danne sig religiøse hierarkier, der står på linje med eller moralsk over politiske hierarkier.

Denne fase er den afgørende i religionens evolution; Bellah pegede også på den i begyndelsen af sin artikel som et relativt veletableret faktum, forud for beskrivelsen af den som én ud af de fem faser (Bellah 1964, 359). I beskrivelserne af den medregnes gerne israelitisk religion, nærmere bestemt den profetiske forkyndelse (jf. Bellah selv, ibid., 366. 368). Nu er der ingen tvivl om, at ganske store dele af den religiøsitet, der findes i Det Gamle Testamente, uden videre henhører under arkaisk religion, også og ikke mindst den prominent fremtrædende præstelige kult med dens præstelige særfunktioner, offerregler og renhedsforskrifter (jf. Lundager Jensen 1998, 814). Og i det hele taget kan Det Gamle Testamentes religiøse verden, inklusive profetismen, bedst forstås som eksempel på en velsignelsesreligion; også i profetismen drejer det sig til syvende og sidst om at restituere en given, og ganske jordisk, orden (jf. Lundager 
Jensen 1998b). Profetismen kan alligevel regnes med til de 'historiske religioner' i den forstand, at der her kan formuleres et modsætningsforhold mellem religion og stat, uanset om denne er lokal og tilhører samme etniske gruppe som profeten eller det drejer sig om en stormagt, baseret på et fremmed område og med andre guder og helligsteder, om end ikke med en principielt anderledes religionsform.

De to sidste faser i Bellahs skema beskriver i udgangspunktet primært kristendommen, hhv. religion i kulturer, der religiøst er fundamentalt præget af kristendom. Den fjerde fase, der som sagt muligvis snarere er en overgangsfase, den tidligt-moderne religionsform, udgøres af de protestantiske retninger, der kommer ud af reformationens brud med den romersk-katolske kirke. I symbolverdenen gennemføres en gennemgribende, indre-kristen afmytologisering (afskaffelse af skærsilden og af helgenuniverset). Frelsen bliver et personligt projekt, principielt tilgængeligt for alle, ikke kun for, eller kun medieret igennem, en afholdenheds-elite. Økonomisk og social handlen bliver identificeret med religiøs handlen. Religiøse hierarkier reduceres i kompleksitet (afskaffelse af ordensvæsen og klerikale indvielsesgrader) og erstattes af en sondring mellem frelste og ikke-frelste, kombineret med de religiøse gruppers strenge sindelagskontrol over deres medlemmer. Religiøse grupperinger underordnes helt staten (den lutherske model) eller etablerer sig som selvstændige organisationer, efterhånden uafhængige af, men ikke i modsætning til staten (den calvinistisk-reformerte model, som Bellah betragter som den potentielt mest moderne af de protestantiske retninger).

Den femte og seneste fase, moderne religion, er beskrevet som den forekom i 1960'ernes USA. Det er formentlig ikke er så forskelligt fra en helt nutidig beskrivelse (fundamentalisme, som Bellah ikke eksplicit tog op i denne artikel, skal nok betragtes som et evolutionært regressivt fænomen). Hvad det religiøse symbolsystem angår, vil moderne religion være endnu mere reduceret end den tidligt-moderne med hensyn til guddommelige aktører, kosmologi, doktriner etc. - som det også kendes fra protestantisk teologis afmytologisering. Traditionelle doktriner defineres som symbolsprog og lægges dermed ud til individuel fortolkningspraksis. Også religiøs praksis overlades til individuelle, eksistentielle valg, fra deltagelse i traditionsbårne ritualer og til individuel, eksistentiel meningssøgning. Religiøse organisationer opretholder ikke længere streng afgrænsning udadtil og barsk disciplin indadtil, men forstår sig som venligtfaciliterende fromhedstilbud for søgende mennesker. Relationen mellem denne religionsform og andre dele af samfundet er uklar; men religionen indretter sig efter (og støtter dermed også op om) en generel individualisme, hvor svaret på mening er overladt til den enkelte, som er fri til at tage imod eller til at afvise forskellige religioners tilbud på mening.

\section{Kulturel og biokulturel evolution}

I sin beskrivelse i artiklen fra 1964 af den tredje af de fem faser, den 'historiske' religion, henviste Bellah til den tysk-amerikanske historietænker Eric Voegelins bog fra 1956, 
Order and History. Voegelins forståelse af græsk filosofi og israelitisk historieforståelse lå imidlertid tæt på det begreb om en 'aksetid' i midten af det første årtusinde f.Kr., som den tyske eksistentialistiske filosof Karl Jaspers havde præget i sin bog Vom Ursprung und Ziel der Geschichte (1949). Jaspers 'aksetid' ('akse' betyder her så meget som 'omdrejning') var en periode, hvori der i et kulturelt område, der strakte sig fra Kina over Indien og Iran til Den Nære Orient og Middelhavsområdet, punktuelt opstod en mental nyorientering, formuleret af store individualister som Kong Fuzi og Lao-Zi, Siddharta, Zarathustra, Platon, israelitiske profeter. Indbyrdes var disse personer (reelle eller fiktive, må man vel i vore dage tilføje), hhv. den tænkning de stod for, naturligvis stærkt forskellige; det fælles var, at de alle problematiserede de politiske og intellektuelle ordninger, der hidtil var blevet taget for givet. Dermed var der etableret menneskehedshistoriske og bevidsthedshistoriske standarder for tænkning, der var og er normative for eftertiden og for nutiden. Begrebet om en aksetid er blevet videreført af forskere og forskningsmiljøer, som baserer sig på Jaspers idé, og som også regner Voegelin som en forløber; blandt vigtige navne kan man nævne sinologen Benjamin Schwartz (1997), egyptologen Jan Assmann og navnlig sociologen S. N. Eisenstadt og miljøet omkring ham (Arnason, Eisenstadt og Wittrock 2005) (jf. Lundager Jensen 2008b, 6); problemstillingen er populært fremstillet i Karen Armstrongs The Great Transformation (2006). ${ }^{19}$

Spørgsmålet om 'aksetid' er perspektivrigt og forskningen allerede så omfattende, at den kunne fortjene en selvstændig introduktion og diskussion, som pladsen ikke tillader her. Jeg vil nøjes med at anføre, at fastholdelsen og påberåbelsen af ansatsen hos Jaspers (der på sin side var inspireret af kultursociologen Alfred Weber, Max Webers broder) ikke har forhindret den senere diskussion i at forholde sig kritisk til alle de mere eller mindre konkrete enkeltheder i Jaspers oprindelige udkast. Hverken selve betegnelsen 'aksetid', vurderingen af store individers betydning eller hvad det nærmere bestemt var i denne periodes nye tanker, der egentlig udmærker den, er gået fri for kritik. Fx foreslog sinologen Benjamin Schwartz $(1975,3)$ at lade en sans for transcendens, der kunne, men ikke nødvendigvis måtte, medføre verdensforsagelse, være det vigtigste kendetegn ved perioden. Arnaldo Momigliano ville ramme det afgørende ved betegnelsen 'age of criticism' ${ }^{20}$, mens filosoffen og videnskabshistorikeren Jehuda Elkana har peget på muligheden for 'andenordenstænkning' ('second-order-thinking'), dvs. refleksion over tænkning, argumentation for, hvorfor noget er sandt eller falsk. Eisenstadt $(2005,537)$ har set det væsentlige ved aksetiden i kombinationen af på den ene side en radikal sondring mellem en ultimativ virkelighed og den dagligdags virkelighed, som blot er en afledning af den ultimative, og på den anden side en radikal som Jaspers tilsigtede.

20 Momigliano, Alien Wisdom, 1975, 8f; citeret i Bellah 2005, 72. 
problematisering af overleverede forestillinger om den fysiske og den sociale verdens indretning, inklusive en stigende refleksivitet og andenordenstænkning.

'Aksetid' er i øvrigt i første omgang et deskriptivt begreb, der ikke forudsætter eller underforstår nogen bestemt forklaring på, hvorfor der i et antal højkulturer i tilnærmelsesvis samme periode opstår en tænkning, der er strukturelt, om ikke indholdsmæssig, sammenlignelig. Mens Jaspers på traditionel vis pegede på store enere, har Eisenstadt og kredsen omkring ham anlagt kulturanalytiske, sociologiske og politologiske synspunkter. Gennemgående er det imidlertid, at mens der i høj grad er tale om en komparativ problemstilling, undgås besvarelser i retning af påvirkning og kulturimport fra en kulturkreds til en anden, af flere grunde end blot den, at sådanne under alle omstændigheder er vanskelige at dokumentere. Der er formentlig altid bestemte forudsætninger, der skal være opfyldt, for at en given tankegang kan formuleres. Men der skal i hvert fald gives bestemte forudsætninger for, at samme tankegang kan overbevise, spredes og få betydning for andre end dens første ophav. Det er disse strukturelle, sociale og kulturelle omgivelser for aksetids-tænkninger, der er genstand for diskussionen, mere end tænkningernes oprindelse og eventuelt gensidige påvirkning og inspiration.

I en artikel fra 2005, "What is Axial about the Axial Age?", har Bellah genoptaget sit anliggende fra artiklen om religiøs evolution fra 1964, og her bliver spørgsmålet om 'historiske religioner', ikke overraskende, eksplicit formuleret ved hjælp af aksetidsbegrebet og den tilhørende forskning, der har udfoldet sig i mellemtiden. Som artiklens titel viser, er den nærmere indholdsmæssige definition eller forståelse af fænomenet aksetid fortsat åbent. Bellahs svar består i at forbinde den kulturelle evolution, som aksetidsproblemstillingen tilhører, med den teori om biokulturel ${ }^{21}$ evolution, som er formuleret af Merlin Donald (jf. Lundager Jensen 2008a). Bellahs to første faser i femfaseskemaet fra 1964, den primitive og den arkaiske religionsform, er præ-aksetidsformer. ${ }^{22}$ Som kommunikationssystemer betragtet var de baseret på gestikulær-mimetisk, ikonisk og mundtlig-sproglig kommunikation, altså ritualer, billeder og mundtlige narrative og poetiske former. Dermed forudsætter de naturligvis den biokulturelle evolution, som har ført frem til homo sapiens, og som i Donalds evolutionære forløb har forløbet igennem først mimetisk-gestikulær kommunikation og hukommelse og

21 Til termen 'biokulturel', jf. Donald 2001, 252; og jf. Institute for the Biocultural Study of Religion (et Internetforetagende, på http://ibcsr.org/ (set 05-01-2011) samt artikelskitsen “Biocultural evolution” på engelsk Wikipedia.

22 I Jan Assmanns sondring mellem 'primær religion' og 'sekundær religion' hører den sekundære (i betydningen 'efterfølgende') religion under aksetiden. Med 'primær religion' menes den religionsform, der fandtes i fx Mesopotamien og Egypten i oldtiden. Men på en række punkter var denne form stærkt forskellig fra primitiv religion. I øvrigt findes der en del binære modstillinger, der alle kan forstås som udtryk for det, som aksetids-begrebet vil fange, fx Bianchis sondring mellem 'etniske' og 'grundlagte' religioner (jf. note 5), Mary Douglas' sondring mellem 'primitiv' og 'moderne' (Douglas 1966), Jonathan Z. Smiths sondring mellem 'lokativ' ('locative') og utopisk (Smith 1972, 147), eller fx den sondring mellem 'velsignelsesreligion' og 'frelsesreligion', som jeg selv har anvendt. 
siden, fra og med homo sapiens, narrativ-mytisk (og det vil sige mundtlig-sproglig) kommunikation og hukommelse.

Aksetiden falder imidlertid sammen med, at tænkningen for første gang bliver skriftbaseret. Skriftens oprindelse og brugen af den til religiøse formål i Den Nære Orient finder sted langt tidligere end aksetiden, allerede i det tredje årtusinde f.Kr.; men skriften er i flere tusind år primært en støtte for hukommelsen i mundtlig kommunikation. I det første årtusind f.Kr. rationaliseres skriften til alfabetskrift, og fastholdt på et relativt billigt og let transportabelt materiale som papyrus bliver den i et hidtil ukendt omfang anvendelig for udbredelse af nye tanker. Det er imidlertid skriften, der er mulighedsbetingelsen for det, som Donald kalder 'teoretisk kultur'. Skriften som eksternt hukommelseslager muliggør ikke kun en mægtig udvidelse af hukommelseskapaciteten, og at der kan ske kommunikation mellem partnere, der ikke er til stede i samme rum og tid; den muliggør også, at tænkeprocessen selv bliver kvalitativt stærkt effektiviseret ved, at den tænkende bevidsthed kan fastholde sine ideer i et eksternt medium. Dermed forøges det træk, der har været gældende fra begyndelsen af den biokulturelle evolution, fra det mimetiske stadie og fremefter, nemlig at tænkning finder sted primært i grupper af mennesker, forsamlede i et rum og med deres individuelle bevidstheder rettet mod et fælles emne. Her kan bevidsthederne kobles sammen til et netværk, hvor tanker og emotioner opstår og kommunikeres rundt, så der dannes en superbevidsthed, der invaderer de biologiske kroppes individuelle bevidstheder - som det fx sker, når en gruppe sammen diskuterer et problem, der er opstillet på en tavle, bivåner opførelsen af opera eller sammen afholder en gudstjeneste. I alle sådanne tilstande er både mimetisk, sproglig og teoretisk kommunikation aktiv og medspillende: kroppe gestikulerer og ansigtsudtryk aflæses, fortællinger fortælles, og visuelle tegn blændes op for de forsamlede kroppe (Donald 1991, 357. 369; 2001, 167f).

Ifølge Donald er det først i moderniteten, med en udbredt alfabetisering af brede kredse af de vestlige befolkninger, at der meningsfuldt kan tales om en 'teoretisk kultur'. Men det udelukker formentlig ikke, at der kan have dannet sig teoretisk kultur i begrænsede elitekredse længe før. Bellahs ide er derfor at identificere aksetiden med den første manifestation af teoretisk kultur. Der ligger ikke i begrebet 'aksetid', at hele befolkninger skulle være blevet grebet af verdensforsagelse, andenordenstænkning og/eller afvisning af traditionelle kosmologier og samfundshierarkier. Men det er ikke befolkningernes flertal, der er kommet til at tegne eftertiden, eller som har sat de standarder, som gælder endnu i nutiden. Det er derimod de stærkt begrænsede, intellektuelle eliter, omkring navne som Kong Fuzi i Kina, upanishadedigtere og Siddharta i det indisk-baserede kulturområde, Platon og Aristoteles i Grækenland, tidligt-jødiske og tidligt-kristne teologer i Middelhavsområdet. Skriften er her en helt uomgængelig forudsætning. Ikke alene ville de nye tankegange for længst være blevet glemt, hhv. transformeret til ukendelighed, hvis transmissionen af dem havde været overladt til mundtlig kommunikation, dvs. til blot biologisk baseret hukommelseskapacitet. De ville næppe engang være blevet formuleret, eller forstået, uden bevidstheder, der var trænet i at tænke ved hjælp af de eksterne, visuelle tegn, der gør det muligt at genkalde 
information, der ellers ville være blevet skubbet ud af den arbejdende hukommelse. ${ }^{23}$

\section{"Nothing is ever lost"}

Donalds bevidsthedsevolutionære skema har en retning igennem tre faser, fra det mimetiske over det narrative til det teoretiske, svarende til tre kommunikationsformer, fra gestik over mundtligt sprog til skriftsprog. Hver senere tilkommende fase indebærer et hegemoni, der underordner tidligere former under sig. I en teoretisk kultur er det skriften og de abstraktioner, den muliggør, der sætter standard og norm for normal kommunikation. Tilsvarende er kompetencer i teoretisk kultur en forudsætning for tilgang til magt og resurser i nutiden (de seneste 20-30 år inklusive kompetencer i elektronisk kommunikation). Men det er samtidig en vigtig pointe hos Donald, at senere tilkomne kommunikationsformer ikke annullerer de tidligere. For det første er det at dominere ikke, eller ikke nødvendigvis, det samme som at udrydde. Homo sapiens er også et mimetisk væsen; og 'homo legens et scribens' (hvis man kan sige det), er også både et mimetisk og et fortællende væsen. For det andet er det ikke givet, at en senere udviklet kommunikationsform, der kan noget andet end de tidligere og ældre, også derfor kan det samme som de tidligere og ældre former. Under normale omstændigheder og uden kriser gælder skriftens hegemoni over talens og talens over gestikkens. Men den teoretiske kultur har i akutte kriser sine begrænsninger. Ved chok, katastrofer, emotionelt højspændte situationer, glædelige som sørgelige, er abstrakte ræsonnementer ifølge den teoretiske kulturs spilleregler irrelevante; og hvor selv den mundtlige kommunikation må give op, er der ingen anden udvej, hvis der overhovedet skal opretholdes kommunikation mellem mennesker, end gestik og kropslige berøringer (jf. Donald 1991, 198). Det evolutionære forløb, der fører frem til moderne mennesker, er altså ikke endimensionalt - hvor senere faser skulle eliminere tidligere faser - men todimensionalt, hvor senere faser supplerer og dominerer, men ikke afskaffer tidligere faser. I fx filosofisk og idehistorisk argumentation høres ofte argumentet, at 'man ikke kan gå tilbage, gå bag om' en eller anden position. I Donalds forløb kan man altid 'gå tilbage', 'regredere' om man vil. I mange situationer er en sådan kommunikativ regression uundgåeligt. En mundtlig-sproglig kommunikation uden mimetisk-gestikulært supplement vil forekomme 'livløs'; en udeladelse af mimetisk-gestikulær kommmunikation i katastrofesituationer vil forekomme hjerteløs.

Men denne todimensionale evolutionsproces, hvor nye lag lægger sig over ældre lag, var også sådan, Bellah forstod religionens evolution i artiklen fra 1964. Evoluti-

23 Donald 1991, 307: "Science and art are both dependent upon external memory devices and thus upon the vast numbers of visuosymbolic codes and conventions stored in the human brain"; id. 2001, 307: “(..) written symbols allow us to decontextualize ideas and abstract them from the concrete situations from which they sprang (...) Until the right symbolic technology came along, certain kinds of thoughts simply could not be thought". 
onsbegrebet implicerede netop ikke, at 'enklere former ikke kan trives og overleve ved siden af mere komplekse former' (Bellah 1964, 358 - som bakterier, svampe, skaldyr, krybdyr, fugle og pungdyr fortsat findes og nogle endda trives vældig godt); "of course no stage is ever completely abandoned; all earlier stages continue to coexist with and often within later ones" (ib., 361). I artiklen fra 2005 (s. 72) bliver dette princip til et slagord: "At this point it might be worth noting a central principle that has governed all my work on religious evolution: Nothing is ever lost".

Religionens historie er en akkumulerende historie, hvor elementer fra ældre udviklingsfaser fortsætter sammen med de senere tilkommende. Også nutidige religioner har stadig som deres centrale handlingsform den primitive, klanagtige forsamling, som Durkheim analyserede: Det at en gruppe mennesker mødes omkring et sæt af fælles, ideelle forestillinger, hvis plads i de individuelle bevidstheder opretholdes og bestyrkes på baggrund af en emotionel og kognitiv kommunikation, der sker i kraft af selve forsamlingens begivenhed. Nutidige religioner fortsætter normalt centrale elementer af den arkaiske religion, fx i form af særlige religiøse bygninger, hvor funktionærer med særlige kompetencer udøver rituelle handlinger, bivånet af en forsamling af lægfolk, eller i kraft af forestillinger om en eller flere antropomorfe guddomme, der er positivt interesseret $\mathrm{i}$ deres menneskelige dyrkeres liv. Men nutidige religioner vil normalt også forudsætte skriftlig fiksering af deres forestillinger, fortællinger og normer, og de vil typisk gøre brug af begrebslig argumentation for disses relevans og overbevisningskraft over for konkurrerende tolkninger.

De lag, der dannes og afsættes af religionens historie, kan fungere samtidig og sammen, men ikke nødvendigvis spændings- og konfliktfrit. Inden for kristendommen har det fx ofte været vanskeligt for mennesker, der tilhørte en skriftbaseret, religiøs elite - for hvem det altså var og er nærliggende at forstå deres religion på aksetidens præmisser - at acceptere legitimiteten af primitive og arkaiske elementer i deres egen religion. Teologiske afmytologiseringsprogrammer på den ene side, rådvildhed over for ritualer eller nedvurdering og afvisning af dem på den anden side vil være nærliggende eksempler. ${ }^{24}$ Men i hvert fald i dette eksempel synes de yngre og de ældre elementer at holde hinanden i skak. Hvis fx forestillinger om en venlig, himmelsk monark, der belønner moralsk god adfærd med fremgang i det jordiske liv, er uantagelig for en teologi, der vil opretholde aksetidens standarder, persisterer en sådan teologi til gengæld parasitært på en uopgiveligt ritualbaseret religionsform, hvis både praktiske og mentale grundstrukturer er arkaisk-narrative. Midt i en demokratisk, rationaliseret og ekstremt individualiseret kultur kan man fortsat, uden at støde særlig mange, lovprise

24 Jf. en nylig meningsudveksling i det grundtvigianske tidsskrift Dansk kirketidende mellem Mogens Lindhardt (2010) og Bent Flemming Nielsen (2011). Og i Donald (1991, 371): “(...) many rituals, including meditation, are an attempt to temporarily reduce the dominance of linguistic, and especially analytic, thought" ('analytic' betyder her så meget som 'teoretisk'). 
Gud som den, der "troner i himlen", omgivet af engle, "som fluks iværksætter, / hvad med et vink kun den vældige bød". ${ }^{25}$

\section{LITTERATUR}



1991 Origins of the Modern World. Three Stages in the Evolution of Culture and Cognition, Harvard University Press, Cambridge, Massachusetts.

2001 A Mind so Rare. The Evolution of Human Consciousness, Norton, New York.

Douglas, Mary

1966 Purity and Danger. An analysis of concepts of pollution and taboo, Routledge \& Kegan Paul, London.

Durkheim, Emile

1994 Les formes élémentaires de la vie religieuse, Presses Universitaries de Freance, Paris [første udgave 1912].

Eisenstadt, Shmuel N.

2005 "Axial Civilizations and the Axial Age Reconsidered", in: Arnason, Eisenstadt \& Wittrock, eds., 531562.

Elkana, Yehuda

1986 "The Emergence of Second-Order Thinking in Classical Greece", in: S.N. Eisenstadt, ed., The origins and diversity of axial age civilizations, State University of New York Press, Albany, 40-64

25 N.F.S. Grundtvigs salme "Lovsynger Herren, min mund og mit indre"; Grundtvig var naturligvis ikke ligefremtnaiv arkaisk; med succes genanvendte og citerede han bevidst arkaiske former som del af sit romantiske mod-oplysningsprojekt. 


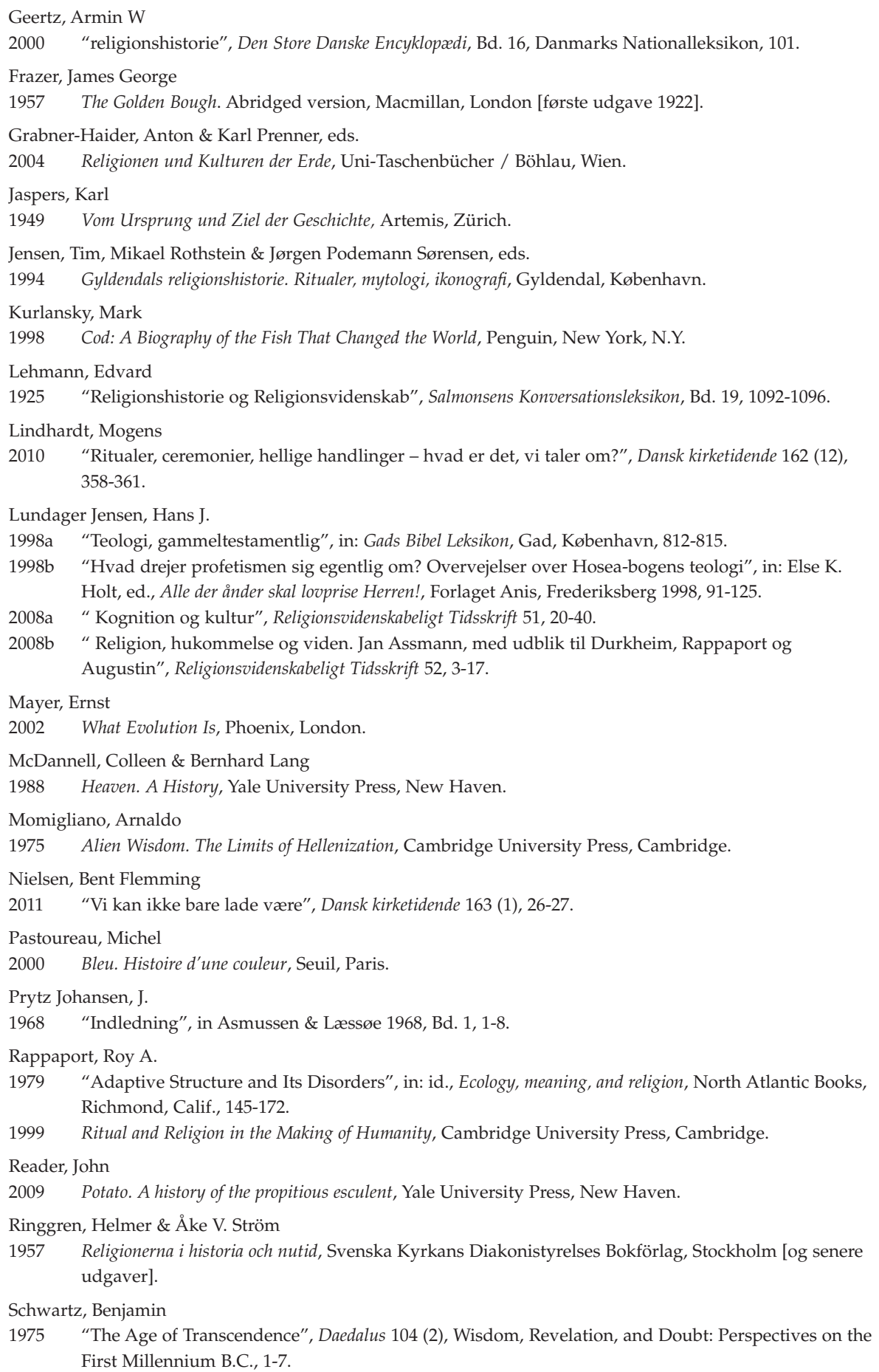


Smith, Jonathan Z.,

1972 "The Wobbling Pivot", The Journal of Religion, 52 (2 ), 134-149.

Voegelin, Eric

1956 Order and History, Vol. 1. Israel and Revelation, Louisiana State University Press, Baton Rouge.

Hans J. Lundager Jensen, professor, mag.art. et dr.theol. Afdeling for Religionsvidenskab, Aarhus Universitet 